\title{
IAMJ
}

INTERNATIONAL

AYURVEDIC

MEDICAL JOURNAL

ISSN: 2320-5091

Impact Factor: 6.719

\section{MANAGEMENT OF TAMAKA SHWASA WITH GHRITA BHRISHTA HARIDRA}

\section{$\underline{\text { Shridharaiah M.H }}{ }^{1}, \underline{\text { Venkatesh }}^{2}$}

${ }^{1} 2^{\text {nd }}$ year P.G Scholar, Department of PG Studies in Kayachikitsa, Shri Vijaya Mahantesh Ayurvedic Medical college \& P.G Research Centre, Ilkal, Karnataka, India

${ }^{2}$ Asst. Professors. Department of PG Studies in Kayachikitsa, Shri Vijaya Mahantesh Ayurvedic Medical College \& P.G Research Centre, Ilkal, Karnataka, India

Corresponding Author: shridharhiremath143@gmail.com

https://doi.org/10.46607/iamj5309092021

(Published Online: September 2021)

Open Access

(C) International Ayurvedic Medical Journal, India 2021

Article Received: 28/08//2021 - Peer Reviewed: 04/09/2021 - Accepted for Publication: 05/09/2021

Check for updates

\section{ABSTRACT}

Shwasa is a chronic condition that developed as a result of Pranavaha sroto dushti, here the shwasa roga is developed due to two types of srodo dushti i.e. sangha (Due to kapha avarodha) and vimarga gamana (of the udana vata). Asthma is a condition that affects the quality of life of an individual. Especially this condition aggravates and worsens in the cold season. Depending on the sign and symptoms Shwasa roga can be compared with Asthma. Asthma is a chronic inflammatory disease that affects the airway of lungs and leads to narrowing of air passage, it is an episodic disease manifested clinically by paroxysms of dyspnoea, tightness of chest along with wheezing sound and coughing usually more at night or early morning. Asthma rapidly increasing in India due to pollution, Among India's 1.31 billion people, about $6 \%$ of children and $2 \%$ of adults are suffering from asthma. ${ }^{[1]}$ Tamaka shwasa is one among the Shwasaroga and it is predominantly Vatakaphajavyadhi. This disease is maintainable by giving proper medication like shodhana (Vmana, Virechana, etc...) and shamana chikitsa (Swasa kutara rasa, swasamrita etc...), if the proper treatment is not given to the patient is proper time, then this condition gets worse and become life-threatening. So, the following case study is explaining about the management of Swasa roga of 8 years history with Ayurvedic medications.

Keywords: Tamaka Shwasa, Deppana, Paachana, Shodhana, Shamana. 


\section{INTRODUCTION}

Madhava nidana explained swasa as 'shvasatvam vegavadurdhvavaatatvam, [2] - it means swasa is the disease which is vegavan and urdhva swasa (fast and upward moment of the breath). It is the most important disease among the pranavaha sroto dushti vikara because it is a life-threatening disease. [3] Asthma is affecting the most of population in India due to air pollution, dust, and food habits. The study conducted by the Barcelona Institute for global health (ISGlobal) revealed that air pollution could not only aggravate asthma but also cause asthma cases among children. In the last 10 years, there has been at least a $10-15 \%$ increase in asthma cases among the children in the city due to an increase in air pollution. ${ }^{[4]}$

In Ayurveda Science, we get many causes of shwasa, among those exposed to dust, smoke, cold breeze etc... causes have been told ${ }^{[5]}$. As ayurveda science, shwasa is of 5 type's maha swasa, urdhva swasa, china swasa, tamaka swasa and kshudra swasa [6][7][8]. Among these 5 types tamaka swasa is having all similar symptoms of asthma-like peenasa (Rhinitis), gurghuraka (wheezing sound), teevra vega (fast breath), moha (unconscious), aruchi(anorexia), trushna (thirsty) ${ }^{[9][10]}$. Due to the fast and upward movement of the breath, the patient's body bends and leads to kasa (cough) with sputum [11]. On spitting sputum, he feels better, on sitting position patients feels comfortable and lying down makes the condition worsen ${ }^{[12]}$. Voice of the patient becomes weak, and he speaks slowly with difficulty [13]. Aggravating factors have been explained in the Ayurveda i.e. Megha (cloudy season), ambu (Rainy season), sheetapragvata (Cold breez), kapha vardhaka ahara vihaara, pragvata (wind from east) [14] it is kashta sadya vyadhi. General line of treatment of Tamaka Shwasa as per classic is Abhyanga with Taila + Lavana, Swedana with Naadi, Prastara \& Shankara Sweda with Snigdha Dravya ${ }^{[15]}$. After Snehana and Svedana Kapha Utkleshakara Ahara should be given to the patient and then Vamana is done, then as per Dosha and Rogi Bala Virechana can also be advised, then Dhumapana is done to eliminate the remaining Dosha ${ }^{[16][17]}$. Once the Shodhana is done then it is further treated with the Shaman Aushadhi. Here below case presentation explains the management of the Tamaka Shwasa with Nitya Virechana for Shodhana and Ghrita Bhrista Haridra as Shaman Oushadhi.

\section{CASE REPORT:}

A 55-year female patient visited Kayachikitsa OPD of RPK Ayurvedic hospital Ilkal on date: 12/02/2021 with chief complaints as a cough for 15 days, Audible breathing sound \& Difficulty in breathing on and off for 8 years. With associated complaints as Disturbed sleep for 1 month and Aruchi for 15 days.

H/O PRESENT ILLNESS: The patient was normal 8 years back, one day she had a fever, difficulty in breathing, a cough along with wheezing sound. She consulted a local doctor and took treatment for fever and cough and got relief. But after few days she noticed that the wheezing sound persist during her work and sleeping time. Then she consulted the same doctor and took some treatment (history not available) but she noticed there was no improvement in her condition. So, she further consulted some higher center for treatment, and she was diagnosed with Asthma and was given some inhalers. After that, her symptoms got reduced but a reoccurrence of the attack was present in the patient. So, she consulted our hospital for further management with above said complaints.

CHIKITSA VRITTANTA: She took some allopathic medication like inhalers, also she tried all other contemporary science medication, but she was not satisfied by all those treatments. Also, she underwent Vamana therapy once in our hospital itself. She partially got relief after the Vamana therapy, but she was unable to continue the treatment further due to her family problems.

KOUTUMBIKA VRITTANTA: Her father and her sister's grandson had the same complaint, but the rests of the family members are healthy

SAMANYA PAREEKSHA: On general examination, we found that BP - 120/80mm/hg, Body temp 97. $3^{\circ} \mathrm{F}$, RR $-26 / \mathrm{min}$, Pulse $-89 / \mathrm{min}$, Weight -63 $\mathrm{Kg}$ and Height $-159 \mathrm{~cm}$. 
ASTAVIDHA PARIKSHA

\begin{tabular}{|l|l|l|}
\hline SN & Pariksha & Findings \\
\hline 1 & Naadi & Pitta - Kapha \\
\hline 2 & Mutra & 3 to 4 times a day and once at night \\
\hline 3 & Mala & 2 times a day and feels unsatisfied. \\
\hline 4 & Jivha & Aliptata (Non coated) \\
\hline 5 & Shabda & Gurgurata (Wheezing) \\
\hline 6 & Sparsha & Anushnasheeta (Normal body temperature) \\
\hline 7 & Drik & Prominent Eyeball \\
\hline 8 & Akruti & Madyama \\
\hline
\end{tabular}

\section{SYSTEMIC EXAMINATION}

- CVS: S1 S2 heard, and no murmur sound was present

- Respiratory System: The shape of chest was bilaterally symmetrical but Suprascapular and bilateral Wheezing was present +++

- Per Abdomen: No organomegaly was present and the abdomen was soft.

LAB INVESTIGATION

\begin{tabular}{|l|l|l|}
\hline SN & Investigation & Result \\
\hline 1 & CBC & As explained in the result \\
\hline 2 & ESR & $40 \mathrm{~mm} / \mathrm{hr}$ \\
\hline 3 & AEC & 650 cells $/$ cumm \\
\hline 4 & USG abdomen & No abnormality found \\
\hline 5 & Chest X-ray & No abnormality found \\
\hline 6 & RBS & $140 \mathrm{mg} / \mathrm{dl}$ \\
\hline 7 & Urine routine & No abnormality found \\
\hline
\end{tabular}

\section{PANCHAKARMA CHIKITSA}

\section{Nitya Virechana}

Procedure:

- Deepana Pachana was done with Hinguvachadi Churna 3gm with Ushna jala (warm water) for 5 days.
- For Nitya Virechana was given Manibadra Guda 1tsf OD with Ushna jala (warm water) for one month.

\section{SHAMANA AUSHADHI}

- Ghrita Bhrista Haridra - (Haridra 100gm + Talisadi Churna 200gm + Abhraka Bhasma 2gm + Ghrita QS) 1 tsf BD with Ushna jala (warm water) BF for 1 month.

\begin{tabular}{|} 
OBSERVATION AND RESULT \\
\begin{tabular}{|l|l|}
\hline INVESTIGATION \\
\hline Hb \\
\hline Total WBC \\
\hline DC Neutrophil \\
\hline \multicolumn{2}{|l}{ Lymphocytes } \\
\hline \multicolumn{2}{|l}{ Eosinophils } \\
\hline & Monocytes \\
\hline ESR & \\
\hline AEC \\
\hline
\end{tabular}
\end{tabular}

\begin{tabular}{|l|l|}
\hline BEFORE TREATMENT & AFTER TREATMENT \\
\hline $10.6 \mathrm{gms} \%$ & $11.80 \mathrm{gms} \%$ \\
\hline $6500($ cells/cumm $)$ & $5900($ cells/cumm $)$ \\
\hline $80 \%$ & $60 \%$ \\
\hline $14 \%$ & $33 \%$ \\
\hline $04 \%$ & $7 \%$ \\
\hline $02 \%$ & $00 \%$ \\
\hline $00 \%$ & $00 \%$ \\
\hline $40 \mathrm{~mm} / \mathrm{hr}$ & $20 \mathrm{~mm} / \mathrm{hr}$ \\
\hline $650 \mathrm{cells} /$ cumm & $370 \mathrm{cells} / \mathrm{cumm}$ \\
\hline
\end{tabular}




\begin{tabular}{|l|l|l|}
\hline COMPLAINTS & BEFORE & AFTER 30 DAYS OF TREATMENT \\
\hline Audible wheezing Sound & +++ & + \\
\hline Cough & Present & Absent \\
\hline Difficulty in breathing & Severe & Reduced \\
\hline Disturbed sleep & Present & Absent \\
\hline Aruchi & Present & Mild improvement \\
\hline
\end{tabular}

\section{DISCUSSION}

The treatment was done in two 2 ways, Panchakarma Chikitsa and Shamana Chikitsa considering the complaints of the patient along the Samprapti Ghataka involved in the patient.

In Panchakarma, Chikitsa Nityavirechana was done for 15 days because the disease originates from the Pittasthana (Amashaya) and a Vaatanulomana effect is needed.

For Nityavirehana purpose Manibadra Guda 1tsf OD with Ushna jala is used because it is indicating the Kushta, Shwasa, Kasa, Udara Roga and Arsha Roga, also it does Vata Kapha Shaman and Vatanulomana [18]

Before going for Nitya Virechana patient was underwent with Deepana and Paachana, for this purpose Hinguvachadi Churna is used as it is having the properties like Vata Kapha Shamaka, Vatanulomana, Deepana, Shroto Shodhana, having Rasa like Katu, Tikta, Kashaya, Lavana, Amla Rasa and Ushna Virya also it is having Rogagnata like Shvasagna, Kasagna, Hikka Nashaka etc... ${ }^{[19]}$

Along with the Nitya Virechana, Shamana Chikitsa was done with Ghrita Bhrista Haridra, it is prepared with a drug combination contains the Haridra, talisadhi churna, and abhraka bhasma.

1. Haridra - It is having the anti allergic property, tikta, katu rasa, ruksha and laghu guna, katu vipaka, ushna virya, vata- kapha nashaka due to katu and ruksha guna and due to tikta it blances pitta $^{[20]}$

2. Talisadi churna - It is indicated in the kaasa, shwasa, Jerna jwara, agnimandya, sangrahani, aruchi. It is also Kapha vata shamaka, Mrudu vatanulomana, deepana, and ushna virya. ${ }^{[21]}$
3. Abhraka bhasma - It is tridosha Hara kaphasthana balya, deepana, and indicated in the kaasa, shwasa, yakshma, madhumeha etc.... ${ }^{[22]}$

\section{CONCLUSION}

In this case study, the patient was suffering from Tamaka Shwasa for 8 years and she tried all systems of medication. In such a patient Ghrita bhrista Haridra has provided good improvement in the symptoms of Tamaka shwasa. Now she leads a good and quality life by getting free of inhalers and she is advised to take Kanakasava in aggravating times and seasons.

\section{REFERENCES}

1. http://globalasthmareport.org/management/india.php\#: $\sim$ :text=Among\%20India's\%201.31\%20billion\%20peo ple,facilities\%20for\%20rich\%20and\%20poor.

2. Sri. Madhavakara, MADHAVA NIDANA, Madhukosha Sanskrit commentary Part 1, By Sri Sudharshana Shastri, Prof. Yadunandana Upadhyaya (Eds). Edition Reprint 2005. Chaukhanmbha Sanskrit Sansthana: Varanasi; Chapter 12/15. Pg 324.

3. Agnivesha. CHARAKA SAMHITA (Ayurveda Dipika's Ayushi Hindi - Commentary). Vd. Harish Chandra Singh Kushwaha (Edt and Translator). Second Part. Chaukhambha Orientalia Varanasi. Reprint Edition 2018. Chikitsa Sthana 17/56. Pg 454.

4. https://www.google.com/amp/s/www.newindianexpre ss.com/cities/hyderabad/2020/feb/15/childhoodasthma-linked-to-air-pollution-study-2103712.amp

5. Agnivesha. CHARAKA SAMHITA (Ayurveda Dipika's Ayushi Hindi - Commentary). Vd. Harish Chandra Singh Kushwaha (Edt and Translator). Second Part. Chaukhambha Orientalia Varanasi. Reprint Edition 2018. Chikitsa Sthana 17/11-13. Pg 446.

6. Agnivesha. CHARAKA SAMHITA (Ayurveda Dipika's Ayushi Hindi - Commentary). Vd. Harish Chandra Singh Kushwaha (Edt and Translator). 
Second Part. Chaukhambha Orientalia Varanasi. Reprint Edition 2018. Sutra Sthana 19/4.4. Pg 211 \& 213.

7. Shrimad Vagbhata - ASTANGA HRDAYA, Nirmala Hindivyaakhya, Dr Brahmanand Tripathi (Eds) Reprint 2019, Chaukhamba Sanskrit Pratiishthana, New Delhi, Nidana Sthana 4/2. pg no - 454.

8. Sri Dallanacharya Evam Sri Gayadasa virachita. SUSHRUT SAMHITA Hindi vyaakhya. Dr. Kevala Krushna Takaral Translator. Chowkanmba Orientalia. Varanasi. Edition reprint 2017, Uttara tandra 51/5. Pg. 484.

9. Agnivesha. CHARAKA SAMHITA (Ayurveda Dipika's Ayushi Hindi - Commentary). Vd. Harish Chandra Singh Kushwaha (Edt and Translator). Second Part. Chaukhambha Orientalia Varanasi. Reprint Edition 2018. Chikitsa Sthana 17/56. Pg 454.

10. Shrimad Vagbhata - ASTANGA HRDAYA, Nirmala Hindivyaakhya, Dr Brahmanand Tripathi (Eds) Reprint 2019, Chaukhamba Sanskrit Pratiishthana, New Delhi, Nidana Sthana 4/7. pg no -455.

11. Agnivesha. CHARAKA SAMHITA (Ayurveda Dipika's Ayushi Hindi - Commentary). Vd. Harish Chandra Singh Kushwaha (Edt And Translator). Second Part. Chaukhambha Orientalia Varanasi. Reprint Edition 2018. Chikitsa Sthana 17/57. Pg 454.

12. Shrimad Vagbhata - ASTANGA HRDAYA, Nirmala Hindivyaakhya, Dr Brahmanand Tripathi (Eds) Reprint 2019, Chaukhamba Sanskrit Pratiishthana, New Delhi, Nidana Sthana 4/8. pg no - 455.

13. Agnivesha. CHARAKA SAMHITA (Ayurveda Dipika's Ayushi Hindi - Commentary). Vd. Harish Chandra Singh Kushwaha (Edt And Translator). Second Part. Chaukhambha Orientalia Varanasi. Reprint Edition 2018. Chikitsa Sthana 17/59. Pg 454.

14. Shrimad Vagbhata - ASTANGA HRDAYA, Nirmala Hindivyaakhya, Dr Brahmanand Tripathi (Eds) Reprint 2019, Chaukhamba Sanskrit Pratiishthana, New Delhi, Nidana Sthana 4/10. pg no -455 .
15. Agnivesha. CHARAKA SAMHITA (Ayurveda Dipika's Ayushi Hindi - Commentary). Vd. Harish Chandra Singh Kushwaha (Edt And Translator). Second Part. Chaukhambha Orientalia Varanasi. Reprint Edition 2018. Chikitsa Sthana 17/71. Pg 457.

16. Agnivesha. CHARAKA SAMHITA (Ayurveda Dipika's Ayushi Hindi - Commentary). Vd. Harish Chandra Singh Kushwaha (Edt And Translator). Second Part. Chaukhambha Orientalia Varanasi. Reprint Edition 2018. Chikitsa Sthana 17/74, 75, 77. Pg 457- 458.

17. Shrimad Vagbhata - ASTANGA HRDAYA, Nirmala Hindivyaakhya, Dr Brahmanand Tripathi (Eds) Reprint 2019, Chaukhamba Sanskrit Pratiishthana, New Delhi, Chikitsa Sthana 4/4,5,6,7. pg no - 609 610.

18. Shrimad Vagbhata - ASTANGA HRDAYA, Nirmala Hindivyaakhya, Dr Brahmanand Tripathi (Eds) Reprint 2019, Chaukhamba Sanskrit Pratiishthana, New Delhi, Chikitsa Sthana 19/31, 32. Pg no - 787.

19. Dr Muhammed Shafeer. V. S.A.M.S (Samhita of Ayurvedic Medical Specialties). $3^{\text {rd }}$ Edition - 20142015. Volume 1. Chaukhamba Publishing house (Distrubuter). New Delhi. Pg -137.

20. https://www.easyayurveda.com/2013/10/23/turmericcurcuma-longa-benefits-usage-dose-side-effects/

21. Dr Muhammed Shafeer. V. S.A.M.S (Samhita of Ayurvedic Medical Specialties). $3^{\text {rd }}$ Edition - 20142015. Volume 1. Chaukhamba Publishing house (Distrubuter). New Delhi. $\mathrm{Pg}-244$ \& 245.

22. Dr Muhammed Shafeer. V. S.A.M.S (Samhita of Ayurvedic Medical Specialties). $3^{\text {rd }}$ Edition - 20142015. Volume 1. Chaukhamba Publishing house (Distrubuter). New Delhi. Pg - 250 \& 251.

\section{Source of Support: Nil Conflict of Interest: None Declared}

How to cite this URL: Shridharaiah M.H \& Venkatesh P: Management Of Tamaka Shwasa With Ghrita Bhrishta Haridra. International Ayurvedic Medical Journal \{online\} 2021 \{cited September 2021\} Available from: http://www.iamj.in/posts/images/upload/2262_2266.pdf 